\section{B A Institute of \\ YK Business Administration \\ 六下 \\ Karachi \\ Leadership and Ideas for Tomorrow}

Business Review

Volume 5 Issue 2 July-December 2010

$7-1-2010$

\title{
Organizational democracy and organization structure link: Role of strategic leadership \& environmental uncertainly
}

Naveed Yazdani

University of Management \& Technology, Lahore Pakistan

Follow this and additional works at: https://ir.iba.edu.pk/businessreview

Part of the Strategic Management Policy Commons

\section{c) (7)}

This work is licensed under a Creative Commons Attribution 4.0 International License.

\section{Recommended Citation}

Yazdani, N. (2010). Organizational democracy and organization structure link: Role of strategic leadership \& environmental uncertainly. Business Review, 5(2), 51-74. Retrieved from https://doi.org/10.54784/ 1990-6587.1244

This article is brought to you by iRepository for open access under the Creative Commons Attribution 4.0 License and is available at https://ir.iba.edu.pk/businessreview/vol5/iss2/4. For more information, please contact irepository@iba.edu.pk. 


\title{
ARTICLE
}

\section{Organizational Democracy and Organization Structure Link: Role of Strategic Leadership \& Environmental Uncertainty}

\author{
NAVEED YAZDANI \\ University of Management \& Technology, Lahore Pakistan
}

\begin{abstract}
This theoretical paper focuses on the issue of implementing democratic principles in modern day organizations facing turbulent and changing environments around them. The paper captures the notion of participatory style of management through the construct; organizational democracy. It traces the origin of this construct from theories and philosophies of political democracy. The paper also briefly describes the notion of economic democracy and why it failed to succeed in the face of partial success of political democracy. The underlying question which the paper raises is the role of organization structure and strategic leadership style in the successful implementation of democratic principles in organizations in the face of a turbulent and dynamic environment. The paper also attempts to raise some thought provoking questions for future research.
\end{abstract}

Keyword : Democratic Principles, Organizational Democracy, Political Democracy, Strategic Leadership, Organizational Structure.

\section{INTRODUCTION}

People who grew up feeling comfortable and secure working for a manufacturing firm appreciate just how elusive stability and security are in these days when the companies across the globe are feeling the enormous impact of globalization on their style of work, leadership, communication, reporting mechanisms, and other structural and contextual dimensions of present-day companies. There are a number of ways in which organizations are coping with the reality of globalization and the need for 'organizational excellence' focus is realized to be more than any other time in industrial history. Recent research has identified four threads of corporate excellence (Daft, 2000, pp. 483). These include, strategic orientation (customer-driven, fast in responding, ability to establish interorganizational links), top management leadership style (leadership vision, bias towards action \& change), organization design (horizontal structure, empowerment of employees, use of electronic technology \& e-commerce) and, corporate culture (creating a climate of trust, sharing information, encouraging productivity through people). 
The impact of globalization is different for different industries. The highvelocity industries like electronics and information technology are probably more exposed to the impact of globalization as compared to typical manufacturing industries, but in general, the focus on 'productivity through people' (Hitt \& Ireland, 1999) has largely meant a participatory style of management and decision-making. This paper presents the notion of organizational democracy to capture the participatory management style within a company and also examines the relationship between this participatory style and other dimensions of the company like strategic leadership style and turbulent environment.

\section{HISTORY AND BACKGROUND OF ORGANIZATIONAL DEMOCRACY}

The term democracy originated from Greek word demokratia where demo means people, and kratia referring to power or rule, so democracy means rule of the people (Powley et al. 2004). The Greeks were no doubt the first to try to build political philosophy theories and Plato equated the three elements of human soul with the three elements of an ideal or just state (Moore \& Bruder, 2001, pp. 266). His notion of democracy is however a degenerated form of plutocracy which results because, "a society cannot hold wealth in honor and ..... establish self-control in its citizens" (Republic). Aristotle too regarded state as an organism and defined democracy as an improper rule by many.

Later on, during the period of renaissance, Nicolo Machiavelli's The Prince (1532) was labeled as, "one of the most famous political treatise of all times" (Moore \& Bruder, 2001, pp. 272). In fact Machiavelli established his reputation as the first one to advocate the notion of power politics. Lock, Rousseau, John Stuart Mill, all mentioned "liberty" and "happiness" as essential ingredients of good governance.

By 19th Century, Karl Marx (1818 - 1883) brought in the issue of "class struggle" in the governance of a society. He also attacked the foundations of capitalist theories by pointing out that workers produce the product but don't own it!

Be it in the West or in the "form of varna and jati in Hindu society" (Presby, Struhl \& Olsen, 2000, pp. 591) in East, most of the philosophers who wrote on politics and its philosophy mention the classes in society and the need for a fair and transparent governance system to bring these classes and factions together in the formulation of a solid and whole system of political governance.

The 20th Century is therefore labeled as the "century of democracy" as the older versions of democracy improved in quality and further experience was gained in governance through democracy and one can witness that from 1985 to 2000, the number of most democratic countries in the world increased from 44 to 82 and the number of authoritarian regimes declined from 67 to 26 (Ringen, 2004). 
Economic democracy, on the other hand has not witnessed such successful proliferation as its political counterpart. Though it seems logical that economic democracy follows from the democratic principles and that economic power should also be under the democratic control but in contrast to political democracy, economic democracy, "does not appear to be something people are ready to take to the streets and fight for" (Ringen, 2004). In the same article on distributional theory of economic democracy, Ringen (2004) captures the failure of economic democracy in the following way:

"Various attempts can be identified through the last century of subordinating economic resources and activities to political control, all failures. The extreme case is that of Soviet-style command economy...... British style nationalization of heavy industry.......French socialists' move under President Mitterrand to nationalize major banks...... Swedish idea of bringing capital under democratic control".

All of these above mentioned endeavors enjoyed brief success but none lasted long.

The advocates of the concept of Inclusive Democracy recognize this failure and are of the view that, "the world is in a multidimensional crisis, caused by concentration of power in the hands of various elites, as a result of the establishment of the economic system of market/growth economy, its political complement in the from of representative democracy" (Gezerlis, 2003). The principle of political democratic equality understood as "one man one vote" does not probably apply to economic democracy and a recent case study of political decision-making in Skanderburg, a small town in Denmark only confirms this (Sorensen \& Torfing, 2003).

Even the modern political democracy is seem to be under attack from factors like, "commercialization of education, media consolidation, news uniformity......extension of application of psychology from the cultivation of consumer tastes to the cultivation of political ideology and voter perception....... and a consumer culture that has elevated material wealth to be all, end all" (Swaney, 2003).

It would now be interesting to pose the question: Why various efforts and experiments to launch economic democracy failed? Why the theory that political control over the economy would be conducive to economic efficiency did not work?

The answers to these questions seem to lie in the "big tradeoff" of the economist Arthur Okum, according to which citizens in democratic societies value both prosperity and equality, they want equality but not at the cost of prosperity (Ringen, 2004). Slowly and gradually issues like poverty, income inequality have been absorbed in the society with little or no political resistance. Political equality has been somewhat achieved in equal rights and the universal vote (at least in the developed countries) while economic equality has been given up, even in these advanced societies, as it not possible without incurring prohibitive costs. Can we imagine a society where everyone has the same 
economic power? The answer to this question seems to be no as it's understood that real economies are comprised of different classes of people with uneven economic power, in contrast to political power, which is more or less equal as one man has only one vote, whatever his/her economic resources may be. Society has an upper, middle and lower class in terms of income and prosperity, though each person within these classes has the same political power of one vote. Laclau noted earlier that, "power which is equally distributed among all members of the community is no power at all" (Marchart, 2003), one can infer that the control and acquisition of economic resources is power as it is not equally distributed across any society in the world.

The political democracy, on the other hand, has seen some success and is probably one of the reasons of successful integration of the 'melting pot' culture of America as it has forged a single nation from people of remarkably diverse racial, religious, and ethnic origins through democratic principles and participatory democracy (Braceras, 2005). Political democracy has to its credit the adoption of Civil Rights Act of 1964 to redress and to eliminate inequality in the treatment of Black Americans. Samuel Loescher while examining the merits of a corporate progressive value addedtax to induce spin-offs by corporate giants to enlarge pluralism, notes the same merits of political democracy in including people to rise, but voices the above mentioned 'big tradeoff' question when he asks, "would adoption of any of these alternatives (tax incentives) be as economically efficient a use of citizens' 'love' for our democratic environment as a massive citizens' campaign for tax incentives to limit corporate power?" (Loescher, 1979).

The next natural question to rise is: If economic democracy has failed due to non homogenous society in terms of income inequality and class struggle, can organizational democracy succeed in organizations?

\section{ORGANIZATIONAL DEMOCRACY}

The idea of political democracy, as we have already seen, is deeply ingrained in Western culture. It is not surprising therefore if the organizations based in the Western economies are viewed as natural setting in which to extend democratic values and practices (Kerr, 2004). Organizational democracy means that members of an organization participate in the processes of organizing and governance (Harrison et al. 2004). There is no doubt that the idea of applying democratic principles to organizations is appealing. It is argued that increase 'voice' (Fenwick, 2005) of the employees (as a result of democratic principles) would lead to higher level of organizational commitment which would further improve implementation rates of the decisions made, reduce dysfunctional behavior in employees and upgrade their skills and abilities due to more participation which would ultimately lead to improved organizational performance and productivity. 
But the literature also points out that organizational democracy practices do not reach out the lowest employees as they are not in a position to capture the 'big picture' of organizational governance and hence the quality of their decisions will be compromised and not up to the mark of organizational requirements (Harrison, et al. 2004). It is also mentioned that organizational democracy is a time consuming process which demands sweeping changes, and fierce resistance from various worker groups and clash of interest of different corporate players would make it even more time consuming and difficult to implement in the organizations.

Organizations are after all much like societies in the sense that they are not homogenous and parallel the rich, middle and poor classes of society as top, middle and lower management hierarchies in organizations. In real economies there is a surplus and no equality (Ringen, 2004) and similarly in organizations there is profit with minimum equality among organizational members. If economic democracy has failed in society, in the face of success of political democracy, can we not assume that democracy in organizations, which are structured more or less like societies, is doomed for failure as well? Is it not the nature of an organizational person to grasp power rather than sharing it or giving it up?

These questions at least caution us to the fact that trying to blindly duplicate political democracy in organizations will end up in failure and trouble. The recent researchers define corporate democracy as, "referring to a system of democratic governance embedded in a supportive organizational structure that includes shared residual claims by all members in combination with democratic decision-making rules" (Harrison, et al. 2004).

We can see that this definition of organizational democracy is subject to 'supporting organizational structures' as a main moderating variable which will decide the fate of the application of democratic principles in organizations. The conceptual and structural differences among different organizations are explained aptly in the following paragraph:

"Some (organizations) are truly command-and-control organizations where attempts by employees or managers to be more democratic are disparaged by owners and senior executives......A few organizations are built not just on democratic principles but are in fact 'democratically designed communities' where ownership, employment and business processes are all aligned to create viable entities that achieve a high level of results...... While larger organizations have difficulty transitioning to a full democracy, many smaller companies have embraced a systemic approach called 'open book management"' (Caimano, 2004). 
In the nutshell, the organizational democracy principles can be summarized as follows:

- Participative management practices

- Increased 'voice' of employees

The basic theory underlying my proposed model of organizational democracy implementation in organizations is based on the interaction between its structural and contextual dimensions. Organizational dimensions fall into two categories: structural and contextual. Structural dimensions provide labels to describe the internal characteristics of an organization and include degree of formalization, specialization, centralization in decision-making, breadth of the span of control and, length and width of the hierarchy, while the contextual dimensions characterize the whole organization, including its size, technology, environment, and goals (Daft, 2000, pp. 16, 17 \& 18). These dimensions of organizations design interact with one another as shown in Figure 1.

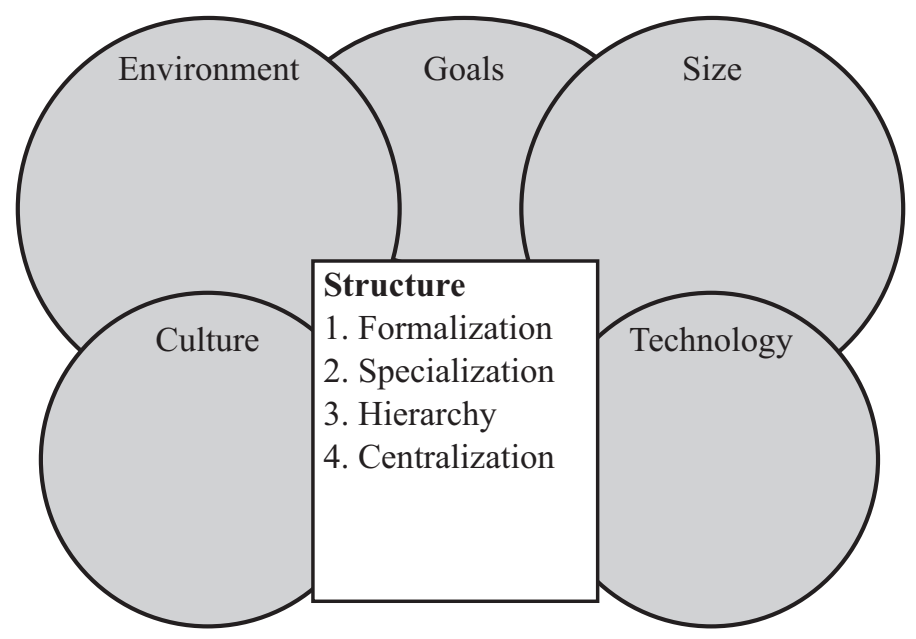

Figure 1: Interacting Contextual and Structural Dimensions of Organization Design Adapted from Daft, 2000, pp. 17: Organization Theory \& Design

The above shown interaction of the contextual and structural dimensions of the organization determine the unique design of that organization and research has proved that these dimensions or variables are interdependent, e.g., large organization size, a routine technology, and a stable environment all tend to create an organization that has greater formalization, specialization, and centralization (Daft, 2000, pp. 20) or mechanistic structure (Daft, 2000, pp. 144; Sharfritz \& Ott, 2001, pp. 201). Similarly, a medium size, a non-routine technology, and a turbulent and dynamic environment 
tend to create an organization that has lesser formalization, specialization, and centralization or in other words, an organic structure.

The underlying theory of my proposed model for successful implementation of organizational democracy is therefore, embedded in the current literature on organizational theory. Since organizational democracy requires participative style of management, the best suited structure to achieve this would be a free flowing organic structure and not the rigid mechanistic structure. In the sections to follow, I will address how successful implementation of organizational democracy depends on the presence of supportive organizational structure and two additional variables; strategic leadership style and change (captured by the environmental uncertainty). My proposed model is shown in Figure 2. This figure is not meant to be a full-blown theoretical model, but it does summarize and integrate some of the findings of the previous research, along with my structure-based predictions. For example, my contention on the connection between successful implementation of organizational democracy and organization structure is that the relationship between the two would be augmented in the presence of two additional variables; a dynamic strategic leadership on top of an organic structure and with a turbulent environment around the organization.

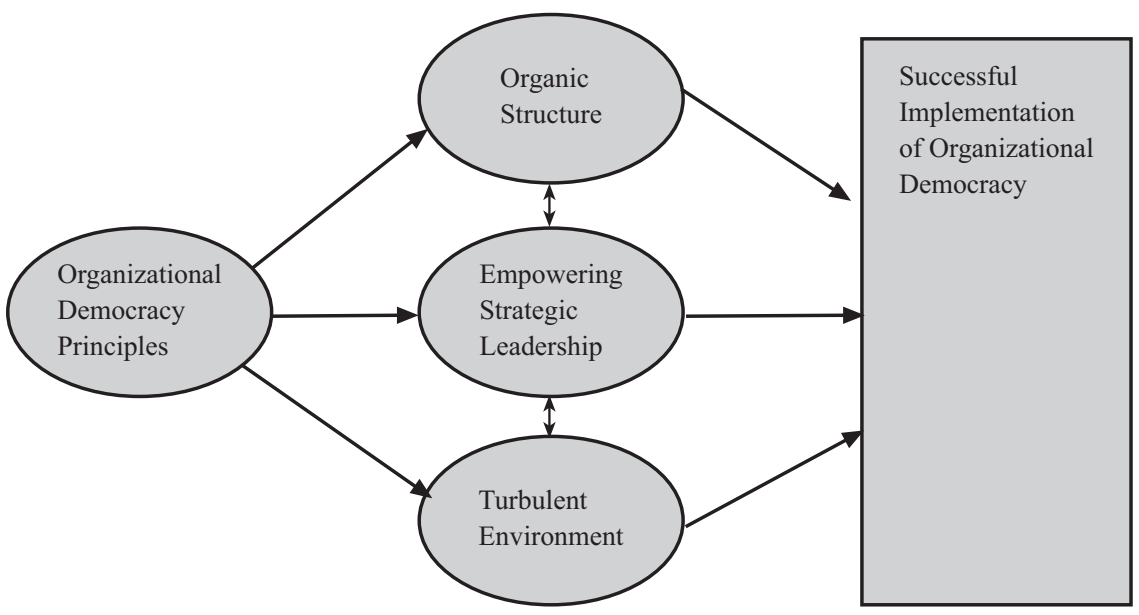

Figure 2: Theoretical Framework Linking Organizational Democracy to organizations' Structure, Strategic Leadership Style and Turbulent Environment. Double-arrows indicate interdependencies.

The link of organizational democracy with supportive organizational structure, strategic leadership and turbulent environment is now described in some detail. 


\section{SUPPORTIVE ORGANIZATION STRUCTURES AND ORGANIZATIONAL DEMOCRACY}

Most organizational theorists like Taylor and Perrow have determined two definitions of organization structure and have evolved the concept of mechanistic versus organic structures (Kennedy, 1983; Ambrose \& Schminke, 2003).

Organizations have a mechanistic or organic structure not because they like to have one, it is because of a particular type of product/service which the organizations is offering and to the degree of environmental stability or the lack of it, around that organization which defines and imposes the structural requirements on the organizations. Burns and Stalker observed that external environment was related to the internal management structure to the extent that when external environment was stable, the internal organization was characterized by rules, procedures and a clear hierarchy of authority. The opposite was observed to be true when the external environment confronting an organization was complex and dynamic. These organizations tended to have loose, free-flowing and adaptive organic structure (Daft, 2000, pp. 144). Various authors and researchers in the field of organization theory have developed sets of characteristics which are intrinsic to mechanistic and organic structure. The following table summarizes some of these characteristics:

Table 1

\begin{tabular}{|l|l|}
\hline Mechanistic Structure & Organic Structure \\
\hline $\begin{array}{l}\text { 1. Tasks are broken down into specialized } \\
\text { separate parts }\end{array}$ & $\begin{array}{l}\text { 1. Employee contribute to the common tasks } \\
\text { of the department }\end{array}$ \\
\hline 2. Tasks are rigidly defined & $\begin{array}{l}\text { 2. Tasks are adjusted and redefined through } \\
\text { teamwork }\end{array}$ \\
\hline $\begin{array}{l}\text { 3. There is a strict hierarchy of authority and } \\
\text { control, rules are many }\end{array}$ & $\begin{array}{l}\text { 3. There's less hierarchy of control and } \\
\text { authority, there are few rules }\end{array}$ \\
\hline $\begin{array}{l}\text { 4. Knowledge and control of tasks are } \\
\text { centralized }\end{array}$ & $\begin{array}{l}\text { 4. Knowledge and control are located anywhere } \\
\text { in the organization }\end{array}$ \\
\hline 5. Communication is vertical & 5. Communication is horizontal \\
\hline
\end{tabular}

Source: Adapted from Richard L. Daft, 7th edition, 2001

These two above mentioned structures are in reality the two formally contrasted forms of management systems, a mechanistic management system which is appropriate in stable conditions and the organic form which is appropriate to changing conditions (Shafritz \& Ott, 2001, pp. 201- 201). 
Michael Porter's framework of competitive strategies of either low cost leadership or differentiation also captures the same structural differences among organizations as a result of their interaction with the environment. His low cost leadership strategy where the organization aggressively seeks efficient facilities, pursue cost reduction, and uses tight controls to produce the product more efficiently (Daft, 2001, pp. 60) is clearly more suitable for mechanistic organizations rather than organic forms where the strategy of differentiation, characterized by organizational attempts to distinguish their products or services from others, would be more suitable.

Broadly speaking, one can conclude that organizations with an efficiency focus would be more prone to have a mechanistic form and organizations which focus on effectiveness (or are less concerned with efficiency) would do better with an organic structure. In a business context, increased efficiency can result from providing greater output for a fixed set of inputs, by marinating output at reduced levels of input or combining the two approaches, the inputs are generally seen as costs which are usually minimized in order to achieve efficiency (Bronn et al. 2005). Other researchers have also defined organizational efficiency as cost-effectiveness or value for money (Smith \& Street, 2005; Lear \& Fowler, 1997) and as fostering, "intra firm compromises economically" (Gellner, Frick \& Sadowski, 1997). It is also mentioned in the literature that corporate efficiency is measured in terms of productivity because increased productivity leads to more competitive cost structure and the ability to offer more competitive products and services (Chowdhury, 2005).

The discussion so far has yielded that organizational democracy cannot be blindly applied across all organizations. There seem to be some prerequisites or some, "internal conditions that facilitate..... democratic organizations" (Rothschild \& Whitt, 1986, pp. 172). I now enlist some of these prerequisites of organizational democracy:

1. a more provisional sense of temporality towards organizations than that of bureaucracy

2. a climate (culture) in which constructive mutual and self-criticism can flourish

3. small size

4. homogenous membership in terms of backgrounds and values

5. a turbulent and dynamic environment around the organization so that the organization's main focus in innovation and idea generation (differentiation) rather than efficiency (cost leadership)

6. a team culture

7. an internal environment where employees trust each other and this trust is emanating from the leadership of the organization

8. a horizontal and flat organization as opposed to a tall and vertical one 
A comparison of the above mentioned prerequisites with the structural characteristics mentioned in Table 1 clearly demonstrates that organic organizations with horizontal communication, employee participation, less vertical hierarchies and decentralization would be much more suited for the practice of democratic principles than a large and tall bureaucratic organization.

Even in organic organizations the assumption that organizational democracy would work like political democracy is a far fetched idea. The top management of organizations is not elected representatives like members of a politically elected government and employees, specially the lower cadre employees, cannot be expected to understand the longer-term repercussions of their decisions and hence the quality of these decisions can be challenged. But organizational democracy in large and bureaucratic organizations seems just out of question. In mechanistic organizations it's not the people but rules and procedures and their meticulous implementation which makes possible the successful realization of a cost leadership strategy in their intensely competitive but relatively stable environments. There is little scope for 'participatory' management systems in mechanistic organizations and hence little scope for the practice of democratic principles in these organizations.

On the basis of the discussion so far, following is the first proposition of this paper:

Proposition 1: Organizational democracy would be implemented more successfully in organizations with an organic structure.

\section{ORGANIZATIONAL DEMOCRACY, STRUCTURES AND STRATEGIC LEADERSHIP}

The study of leadership has progressed from a simple description of traits to examining complexities of interaction between leaders and followers and since 1940s, the main approach in studying leadership focuses on leadership styles (Athanasaw, 2003).

Hambrick and Pettigrew (2001) note two distinctions between the terms leadership and strategic leadership; first, leadership theory refers to leaders at any level in the organization, whereas the strategic leadership theory refers to the study of people at the top of the organization, second, in contrast to the micro focus of leadership research on relationship between leaders and followers, strategic leadership research focuses on executive work, not only as a relational activity but also as a strategic activity and a symbolic activity. One branch of leadership research which has proven useful to the study of CEO-level management is the framework of transactional/transformational leadership (Vera and Crossan, 2004). This framework stems from the visionary or charismatic school of leadership theory, which along with other five main schools, trait school, behavioral or style school, contingency school, emotional intelligence school 
and, competency school, formulate the six main themes or schools of leadership theories over the past 70 years or so (Dulewicz \& higgs, 2003; Handy, 1982; Partington, 2003). Recent work has suggested that the positive relationship between charismatic leadership and performance found in earlier studies also holds true at the strategic (CEO) level (Waldman et al., 2004).

Transactional leadership, primarily task-focused (Turner \& Muller), motivates individuals primarily through contingent-reward exchanges. These leaders set goals, articulate explicit agreements regarding what the leader expects from organizational members and how they will be rewarded for their efforts and commitment, and provide constructive feedback to keep everyone on task (Howell \& Hall-Merenda, 1999; Jung and Avolio, 1999). Operating within an existing system, transactional leaders seek to strengthen an organization's culture, strategy, and structure and hence is similar in nature to the cultural maintenance for of leadership described by Trice and Beyer (1993) They clarify the performance criteria for followers and also explain to them what they would receive in return (Hartog, Muijen and Koopman, 1997; Waldman et al., 2001).

Transformational leadership, primarily people-focused (Turner \& Muller, 2005) in contrast, is charismatic, inspirational, intellectually stimulating, and individually considerate (Avolio et al., 1999; Carless, 1998; Hartog et al., 2004). Some researchers have treated charisma and transformational leadership as distinct concepts but others mention transformational leaders talking of articulating a vision, which creates considerable loyalty and trust among the followers (Tichy and DeVanna, 1986) which sounds very similar to charisma. Similarly, some researchers use the term empowering leadership to capture five themes of this type of leadership, the themes are leading by example, participative decision making, coaching, informing and showing concern for team members (Srivastava, Bartol and Locke, 2006). These five themes of empowering leadership are no different than the definition of charismatic/transformational leadership. In this paper, therefore, the terms transformational and charismatic leadership are used interchangeably. Similarly, House and Shamir (1993) propose that charisma is the central concept in the theories of charismatic, transformational or visionary leadership. Transformational/charismatic leaders help individuals transcend their self-interest for the sake of the larger vision of the firm. They inspire others with their vision, create excitement through their enthusiasm, and have everybody do the same. These leaders seek to raise the consciousness of followers by appealing to higher ideals and moral values such as liberty, justice, equality, peace, and humanitarian, and not to basic emotions such as fear, greed, jealousy, or hatred. Transformational leadership has been specified as an important mechanism for introducing organizational change in the recent research literature (Masood, Dani, Burns and Backhouse, 2006).

Based on these research findings, following is the second proposition formulated in this paper: 
Proposition 2: Organizational democracy would be implemented more successfully in organizations with an organic structure and where the strategic leadership style is that of empowering or transformational/charismatic type.

\section{Organizational Democracy, Structures, Strategic Leadership and Turbulent Environment}

The relationship between organizations and environment is perhaps the most popular and conceptually appealing aspect of the structural-contingency model (Hrebiniak and Snow, 1980). Present day theorists view the interaction between the organization and the environment as the critical variable in determining the nature of internal strategies and processes and point to the need to develop appropriate systems of differentiation and integration, depending on the degree of turbulence within the environment (Shipton, Dawson, West and Patterson, 2002).

The organizational environment is typically divided into two levels. The most influential level is termed the task environment and consists of firms that directly influence the setting and achievement of goals for a particular organization. The general environment, on the other hand, has no out boundary and includes the source of conditions, trends, political pressures, norms and social trends. Changes originate in the general environment and, in turn, influence task environment phenomena (White, 1998) and it is also suggested that organizational uncertainty is derived from failure to understand a task environment and from interdependence with elements of task environment (Lang and Lockhart, 1990).

Milliken (1987), in a review of the literature and research on environment, developed a general definition of environmental uncertainty, calling it "an individual's perceived inability to predict an organization's environment accurately" because of a "lack ... of information" or "an inability to discriminate between relevant and irrelevant data" (Buchko, 1994). Key managers in the industry rely on, "some minimum level of perceived predictability - specifically, predictability relating to customer demands and competitor actions" to formulate strategies to cope with the environmental uncertainty (Dickson and Weaver, 1997).

Environmental uncertainty has also been defined as the degree to which an environment is stable-unstable, simple-complex, and concentrated-dispersed (Karimi, Somers and Gupta, 2004). The stable-unstable dimension refers to whether the elements in organization task environment are dynamic. Organizational task environments, "include all the sectors with which organizations interact directly and have the potential to impact organizations' ability to achieve their goals and typically include industry, market sectors, raw materials, human resources, and, perhaps, international sectors" (Daft, 2001). Under unstable conditions, organization task environment shift abruptly, and companies react with aggressive moves and countermoves regarding advertising and new products. 
Dynamism is characterized by the rate of change and innovation in production and service technologies, as well as the uncertainty of customer taste and actions by the firm's main industries. Firms in more unstable environments face a number of similar external elements that change frequently and unpredictably. Environmental dynamism poses the challenge of planning and control as managers must cope with unpredictable external events and must seek to integrate and improve operating processes. To do so the managers and decision-makers require detailed, timely information that allows them to coordinate the flow of activities, at all levels in organization, with an understanding of process dynamics and their relationship to organizational performance. As environmental uncertainty increases, interdependency becomes more important due to increased need for coordination for internal resolutions and the need to link the organization with the key elements in the task environment to detect, bring, and send information about changes in the environment (Maier et al. 1997; Schwab et al. 1985).

The simple-complex dimensions concern environmental complexity and refer to heterogeneity, which is the degree of similarity or differentiation within the organization task environment. Firms in these environments face many distinctive elements that remain the same or change slowly and require very different marketing, production, and administrative practices. Organizations in such environment have a great need for information processing to reduce uncertainty and it is expected that the decision-makers in these organizations are more likely to face a higher frequency of nonroutine and interdependent tasks.

The concentrated-dispersed dimensions refer to scarce material and financial resources and the need to ensure the availability of resources. Hostile task environments are characterized by severe regulatory restrictions, a harsh and overwhelming business climate, intense competition in price, product, technology, and distribution, a shortage of labor or raw material and the relative lack of exploitable opportunities and resources (Miller and Friesen, 1983). Under these conditions, the organizations' responses can be in the forms of greater integration and coordination and establishing favorable links with key elements of its task environment. These responses can be in the form of joint ownership, contract, joint ventures, interlocking directorates, executive recruitment, buffering, advertising, and public relations (Daft, 2001; Kopp and Litschert, 1980).

Some companies also use innovation, marketing differentiation strategies, high quality, auxiliary services, convenient distribution, and comprehensive warranties to induce customer loyalty in the face of a changing and turbulent environment (Miller, Droge and Toulouse, 1988). The firm's perception of environmental uncertainty has been attributed to its perceptions of the level of control it exerts over its environment (Perrow, 1967). Research evidence further suggest that firms operating in highly uncertain environments are more likely to form exchange relationships that mitigate their organizational risk levels; conversely, firms that perceive that they have a greater degree 
of control over their current and future technologies (more certain environment) are less likely to forge relational customer-supplier exchange relationships (Pfeffer and Salanick, 1978; Fink, Edelman and Hatten, 2006).

The use of uncertainty as an environmental variable flows from an informationprocessing view of organizations, a view that explains organizational adjustments, like changes in structure, by variations in information, as filtered by managerial perceptions of their external environment (Koberg, 1987). Duncan (1972) made a distinction between the internal and external environments of a company. The internal environment refers to all those internal forces operating within an organization itself, such as the company's goals and objectives, nature of its' products and services, communication processes and networks within the organization, and the educational background of the employees; the external environment refers to all those forces outside the company, such as customers, competitors, suppliers, governments, and trade unions (Tung, 1979). Overall, the literature suggests that firms should adopt a more organic structure to cater to a more complex environment where jobs are less specialized and more complex, companies should apply a mechanistic structure to a more predictable environment with greater subdivision of tasks and similar job assignments (Chang, Lin and Sheu, 2002). Similarly, other theorists and researchers have suggested that increase in environmental complexity increases need for strategic activities like developing interorganizational linkages to cope with complexity and uncertainty of the environment (Stearns, Hoffman and Heide, 1987). The recognizable pattern of organizational responses to environmental conditions is determined not so much by the objective characteristics of organization-environment interactions as by managerial perceptions of the strategic importance of the critical areas contained within different organizational functions. Researchers investigating the link between perceived environmental uncertainty (PEU) and the relative strategic importance of different organizational functions have found that "externally oriented functions (e.g., market research and product development) received emphasis with high PEU but internallyoriented functions (e.g., production) assumed more strategic importance with low PEU (Hitt, Ireland and Palia, 1982). Organizational contingency theories traditionally have argued that when contextual variables (technology, environmental conditions) are matched with appropriate organizational responses (centralization, communication, formalization, subdivision of work), effectiveness of the unit will be enhanced (Morrow, 1981).

\section{Environment and Strategic Leadership Link}

While developing a theoretical model of the impact of CEO and top management leadership styles and practices on organizational learning, Vera and Crossan (2004) argue that, "in times of change, these (organizational learning) processes make evident the need to alter a firm's institutionalized learning - a task best suited to transformational leadership....in times of stability, organizational learning processes serve to refresh, reinforce, and refine current learning - a task best suited to transactional leadership". 
https://ir.iba.edu.pk/businessreview/vol5/iss2/4

DOI: https://doi.org/10.54784/1990-6587.1244

Business Review - Volume 5 Number 2

July - December 2010

Howell and Higgins (1990) suggest that champions of innovation have characteristics of transformational leaders. These leaders rely on innovation and risk taking more than non-champions. Pinto and Slevin (1989) found that aspects of transformational leadership, such as mission awareness, predicted the success of $R \& D$ projects. Similarly, Keller's (1992) work found that transformational leadership of project leaders in R\&D organizations predicted performance at two times, concurrently and a year after leadership was measured. Thite (2000) notes that transactional leadership also predicts project success but to a lesser extent than transformational leadership (Berson and Linton, 2005).

Organizations exhibit three types of inertial forces; cognitive inertia, motivational inertia and obligation inertia (Gersick, 1991). During changing environments, overcoming these organizational inertial forces is viewed as an important condition for improving organizational performance (Tichy \& DeVanna, 1990). Charismatic leaders overcome cognitive inertia (inability to think beyond one's own schema) because their strong values shape choices concerning strategy as they can create exciting visions of future and promote unconventional problem-solving approaches. Motivational inertia (desire to avoid change) can be overcome through a leader's ability to provide followers with confidence that changes can be positive. Finally, obligation inertia (commitment to constituencies) can be overcome through leader's ability to change current contractual relationships with various stakeholders (Agle et al., 2006).

Transformational leaders, in unstable, shaky, risky, or crisis situations take on greater symbolic importance as the followers feel the need for direction and guidance under these conditions, and therefore, willingness to a follow a leader may be more pronounced in unstable and turbulent environments (Agle et al., 2006). Studies also suggest that crisis and the associated stress and uncertainty may foster the emergence of charismatic leadership and Waldman's (2001) study empirically prove that charismatic leadership of CEO is highly related to an organization's performance when the environment is perceived to be uncertain and volatile, and the same link between charismatic leadership and performance, does not come strongly in the face of certain and stable environment.

Based on the above discussion, following is the third proposition of this paper: Proposition 3: Organizational democracy would be implemented more successfully in organizations with an organic structure and where the strategic leadership style is that of empowering or transformational/charismatic type and where the surrounding task environment of the organization is dynamic (complex and unstable). 


\section{CONCLUDING REMARKS}

This paper raises the critical question of the suitability of the application of organizational democracy in different organizations and under the influence of the interaction between their structural and contextual dimensions, resulting in unique settings or organizational designs and as such should serve as a food for thought for researchers to probe the following research areas:

- Empirical testing of the underlying theme of this paper and the proposed model (figure 1) that organizational democracy cannot be justified in mechanistic structures with stable environments around them and that it would be more successful in organic set ups in turbulent environments and where the leadership style of the top management is empowering or transformational/charismatic.

- The cultural differences across various nations and their role in preparing organizations for organizational democracy also need to be empirically studied. For example, Western societies with their long history of involvement with democracy are perhaps more suited to apply democracy in organizations in contrast to those nations where democracy has not been the preferred style of governance.

- Certain industrial sectors, for example service sector, have inherently different structural requirements as compared to organizations in production sector. It would make an interesting study to examine the possibility of employing organizational democracy principles in service organizations and to gauge their success in terms of productivity and performance to those service sector organizations where principles of democracy are not applied.

- Similarly in high-velocity industries like Information Technology and Electronics, where the environment is dynamic and turbulent and the rate innovation is high, the need for empowering leadership, horizontal structures and organizational democracy would be more pronounced as compared to other traditional production-focused industries.

- Organizational democracy as a construct needs further development in the sense that measuring instruments be developed to try to measure it empirically. Their relationships with other organizational variables like performance, job satisfaction, strategic leadership style and, uncertain environment would also shed further light on this construct. 


\section{REFERENCES}

Agle, Bradley R.; Nagarajan, Nandu J.; Sonnenfeld, Jeffrey A.; Srinivasan, Dhinu. (2006). Does CEO Charisma Matter? An Empirical Analysis of the Relationships Among Organizational Performance, Environmental Uncertainty, and Top Management Team Perceptions of CEO Charisma, Academy of Management Journal, 49 (1), 161 - 174.

Ambrose, L. Maureen; Schminke, Marshall. (2003). Organization Structure as a Moderator of the Relationship Between Procedural Justice, Interactional Justice, Perceived Organizational Support and Supervisory Trust, Journal of Applied Psychology, 88, 295 - 305.

Athanasaw, Danny L. (2003). Leadership Styles as Perceived by Career Senior Service Executives, International Journal of Public Administration, 26 (10 \& 11), $1207-1236$

Avolio, Bruce J.; Bass, Bernard M.; Jung, Dong I. (1999). Re-examining the Components of Transformational and Transactional Leadership Using the Multifactor Leadership Questionnaire, Journal of Occupational and Organizational Psychology, 72, $441-462$.

Backes-Gellner, Uschi; Frick, Bernd; Sadowski, Dieter. (1997). Codetermination and Personnel policies of German Firms: the influence of Works Councils on turnover and further training, The International Journal Human Resource Management, 8:3, $328-347$.

Bass, B. M. (1985). Leadership and Performance Beyond Expectations. New York: The Free Press.

Berson, Yair; Linton, Jonathan D. (2005). An Examination of the relationships Between Leadership Style, Quality, and Employee Satisfaction in R\&D Versus Administrative Environments, R\&D Management, 35 (1), 51 - 60.

Braceras, C. Jennifer. (2005). Not Necessarily in Conflict: Americans can be Both United and Culturally Diverse, Harvard Journal Law \& Public Policy, $29,27-32$.

Bronn, Carl; Bronn, Simcic, Peggy. (2005). Reputation and Organizational Efficiency: A Data Envelopment Analysis Study, Corporate Reputation review, $8,45-58$. 
Buchko, Aaron A. (1994). Conceptualization and Measurement of Environmental Uncertainty: An Assessment of the Miles and Snow Perceived Environmental Uncertainty Scale, Academy of Management Journal, 37 (2), 410 - 425.

Caimano, F. Vincent. (2004). Executive Commentary, Academy of Management Executive, 18, $96-97$.

Carless, Sally A. (1998). Assessing the Discriminant Validity of Transformational Leader Behavior as Measured by the MLQ, Journal of Occupational and Organizational Psychology, 71, 353-358.

Chang, Shih-Chia; Lin, Neng-Pai; Sheus, Chwen. (2002). Aligning Manufacturing Flexibility with Environmental Uncertainty: Evidence from High-Technology Component Manufacturers in Taiwan, International Journal of Production Research, 40 (18), 4765 - 4780.

Chowdhury, D. Shamsud. (2005). The Dominant Perspective, Institutional Ownership, And Corporate Efficiency: An Empirical Investigation, IJCM, 15, $255-271$.

Daft, L. Richard. Organization Theory \& Design, (7th Edition, 2001, p. 60, 144 \& 210), South-Western Publishing.

Dickson, Pat H.; Weaver, K. Mark. (1997). Environmental Determinants and Individual- Level Moderators of Alliance Use, Academy of Management Journal, 40 (2), $404-425$.

Dulewicz, V.; Higgs, M. J. (2003). Design of a New Instrument to Assess Leadership Dimensions and Styles, Henley Working Paper Series, HWP 0311. Henley-on-Thames, UK: Henley Management College.

Duncan, R.B. (1972). Characteristics of Organizational Environments and Perceived Environmental Uncertainty, Administrative Science Quarterly, 17, $313-327$.

Fenwick, Tara. (2005). Conception of Critical Human Resource Development: Dilemmas for Theory and Practice, Human Resource Development International, $8,225-238$.

Gezerlis, Alexandros. (2003). Introduction, Democracy and Nature, 9, 321 331. 
Fink, Robert C.; Edelman, Linda F.; Hatten, Kenneth J. (2006). Relational Exchange Strategies, Performance, Uncertainty, and Knowledge, Journal of Marketing Theory and Practice, 14 (2), 139 - 153

Gersick, C. J. G. (1991). Revolutionary Change Theories: A Multilevel Exploration of the Punctuated Equilibrium Paradigm, Academy of Management Review, 16, $10-36$.

Hambrick, D.; Pettigrew, A. (2001). Upper Echelons: Donald Hambrick on Executives and Strategy, Academy of Management Executive, 15 (3), 36 - 44.

Handy, C. B. (1982). Understanding Organizations, London: Penguin.

Harrison, S. Jaffrey; Freeman, Edward. (2004). Special Topic: Democracy In and Around Organizations, Academy of Management Executive, 18, 49 - 53.

Hartog, Deanne N.; Muijen, Jaap J.; Koopman, Paul L. (1997). Transactional Versus Transformational Leadership: An Analysis of the MLQ, Journal of Occupational and Organizational Psychology, 70, $19-34$.

Hitt, Michael A.; Ireland, R. Duane. (1999). Achieving and Maintaining Strategic Competitiveness in the 21st Century: The Role of Strategic Leadership, Academy of Management Executive, 13, 43 - 57.

Hitt, Michael A; Ireland, R. Duane; Palia, K.A. (1982). Industrial Firms' Grand Strategy and Functional Importance: Moderating Effects of Technology and Uncertainty, Academy of Management Journal, 25 (2), 265 - 298.

Hoogh, Annebel H.B.; Hartog, Deanne N.; Koopman, Paul L.; Thierry, Henk; Van Den Berg, Peter T.; Weide, Joost G.; Wilderom, Celeste P.M. (2004). Charismatic Leadership, Environmental Dynamism, and Performance, European Journal of Work and Organizational Psychology, 13 (4), 447 - 471.

Howell, J.; Hall-Merenda, K. (1999). The Ties That Bind: The Impact of LeaderMember Exchange, Transformational and Transactional Leadership, And Distance on Predicting Follower Performance, Journal of Applied Psychology, $84,680-694$.

Howell, J. M.; Higgins, C. A. (1990). Champions of Technological Innovation, Administrative Science Quarterly, 35, 317 - 341. 
Hrebiniak, Lawrence G.; Snow, Charles C. (1980). Industry Differences in Environmental Uncertainty and Organizational Characteristics related to Uncertainty, Academy of Management Journal, 23 (4), 750 - 759.

Jung, Dong I.; Avolio, Bruce J. (1999). Effects of Leadership Style and Followers: Cultural Orientation on Performance in Groups and Individual Task Conditions, Academy of Management Journal, 42 (2), 208 - 218.

Karimi, Jahangir; Somers, Toni M.; Gupta, Yash P. (2004). Impact of Environmental Uncertainty and Task Characteristics on User Satisfaction with Data, Information Systems Research, 15 (2), 175 - 193.

Kennedy, M. Anita. (1983). The Adoption and Diffusion of New Industrial Products: A Literature Review, European Journal of Marketing, 17, 31 - 77.

Kerr, L. Jaffrey. (2004). The Limits of Organizational Democracy, Academy of Management Executive, 18, $81-95$.

Koberg, Christine S. (1987). Resources Scarcity, Environmental Uncertainty, and Adaptive Organizational Behavior, Academy of Management Journal, 30 (4), $798-807$.

Kopp, Daniel G.; Litschert, Robert J. (1980). A Buffering Response in Light of Variation in Core Technology, Perceived Environmental Uncertainty, and Size, Academy of Management Journal, 23 (2), 252 - 266.

Lang, James R.; Lockhart, Daniel E. (1990). Increased Environmental Uncertainty and Changes in Board Linkage Patterns, Academy of Management Journal, 33 (1), $106-128$.

Lear, Van Williams; Fowler, Lynette. (1997). Efficiency and Services in the Group Home Industry, Journal of Economic Issues, XXXI, 1039 - 1050.

Loescher, M. Samuel. (1979). Limiting Corporate Power, Journal of Economic Issues, XIII, $557-571$.

Maier, J.L.; Rainer, A. Synder. (1997). Environmental Scanning for Information Technology, Management Information Systems, 14 (2), 177 - 200.

Marchart, Oliver. (2003). The Other Side of Order: towards a Political Theory of Terror and Dislocation, Parallax, 9, $97-113$. 
Masood, S. A.; Dani, S. S.; Burns, N. D; Backhouse, C. J. (2006). Transformational Leadership and Organizational Culture: The Situational Strength Perspective, Journal of Engineering Manufacturing, 220, 941 - 949. Milliken, F.J. (1987). Three Types of Perceived Uncertainty about the Environment: State, Effect, and Response Uncertainty, Academy of Management Review, 12, $133-143$.

Moore, Noel Brooke; Bruder, Kenneth. Philosophy: The Power of Ideas, (5th Edition, 2002, p. ), McGraw-Hill.

Miller, Danny; Droge, Cornelia; Toulouse, Jean-Marie. (1988). Strategic Process and Content as Mediators Between Organizational Context and Structure, Academy of Management Journal, 31 (3), 544 - 569.

Miller, D.; Friesen, P. H. (1983). Strategic making and Environment: The Third Link, Strategic Management Journal, 4, 221 - 235.

Morrow, Paula C. (1981). Work Related Communication, Environmental Uncertainty, and Subunit Effectiveness: A Second Look at the Information Processing Approach to Subunit Communication, Academy of Management Journal, 24 (4), $851-858$.

Partington, D. A. (2003). Managing and Leading. In J. R. Turner (Ed.), People in Project Management. Aldershot, UK: Gower.

Perrow, Charles. (1967). A Framework for the Competitive Analysis of Organizations, Administrative Sociological Review, 32 (2), $194-208$.

Pinto, J.; Slevin, D. (1989). Critical Success Factors in R\&D Projects, Research - Technology Management, 32, $12-18$.

Powley, H. Edward; Fry E. Ronald; Barrett, J. Frank; Bright S. David. (2004). Dialogic Democracy Meets Command and Control: Transformation through the Appreciative Inquiry Summit, Academy of Management Executive, 18, 67 -80 .

Presby, M. Gail; Struhl, J. Karsten; Olsen, E. Richard. The Philosophical Quest: A Cross-Cultural Reader, (2nd Edition, 2000, p.), McGraw-Hill.

Ringen, Stein. (2004). A Distributional Theory of Economic Democracy, Democratization, $11,18-40$. 
Rothschild, Joyce; Whitt, Allen. J. The Cooperative Workplace: Potentials and Dilemmas of Organizational Democracy and Participation, (3rd Edition, 1986, p. 172), Cambridge University Press.

Schwab, R. C.; Ungson, R.; Brown, W. R. (1985). Redefining the Boundary Spanning-Environment Relationship, Journal of Management Studies, 11 (1), $75-86$.

Shafritz, M. Jay; Ott, Steven J. Classics of Organization Theory, (5th Edition, 2001, p. 201 -202), Wadsworth.

Shamir, B.; House, R. J.; Arthur, M. B. (1993). The Motivational Effects of Charismatic Leadership: A Self-Concept Based Theory, Organization Science, 4, $577-594$.

Shipton, Helen; Dawson, Jeremy; West, Michael; Patterson, Malcolm. (2002). Learning in Manufacturing Organizations: What Factors Predict Effectiveness, Human Resource Development International, 5 (1), 55 - 72.

Smith, C. Peter; Street, Andrew. (2005). Measuring the Efficiency of Public Services: the Limits of Analysis, Journal of Royal Statistical Society, 168, 401 -417 .

Sorensen, Eva; Torfing, Jacob. (2003). Network Politics, Political Capital, and Democracy, International Journal of Public Administration, 26, 609 - 634.

Srivastava, Abhishek; Bartol, Kathryn M.; Locke, Edwin A. (2006). Empowering Leadership in Management Teams: Effects on Knowledge Sharing, Efficacy, and Performance, Academy of Management Journal, 49 (6), 1239 - 1251.

Stearns, Timothy M; Hoffman, Alan N; Heide, Jan B. (1987). Performance of Commercial Television Stations as an Outcome of Interorganizational Linkages and Environmental Conditions, Academy of Management Journal, 30 (1), 71 -90 .

Swaney, A. James. (2003). Are Democracy and Common Property Possible on Our Small Earth? Journal of Economic Issues, XXXVII, 261 - 290.

Thite, M. (2000). Leadership Styles in Information Technology Projects, International Journal of Project Management, 18, 235 - 241. 
Tichy, N.; DeVanna, M. (1990). , The Transformational Leader, New York: Wiley.

Trice, H.M.; Beyer, J.M. (1993). , The Cultures of Work Organizations. Englewood Cliffs, NJ: Prentice-Hall.

Tung, Rosalie L. (1979). Dimensions of Organizational Environments: An Exploratory Study of Their Impact on Organization Structure, Academy of Management Journal, 22 (4), 672 - 693.

Turner, Rodney; Muller, Ralf. (2005). The Project Manager's Leadership Style as a Success Factor on Projects: A Literature Review, Project Management Journal, 36 (1), $49-61$.

Vera, Dusya; Crossan, Mary. (2004). Strategic Leadership and Organizational Learning, Academy of Management Review, 29 (2), 222 - 240.

Waldman, D. A.; Javidan, M.; Varella, P. (2004). Charismatic Leadership at the Strategic Level: A New Application of Upper Echelons Theory, Leadership Quarterly, 15, 355-381.

Waldman, David A.; Ramirez, Gabriel G.; House, Robert J.; Puranam, Phanish. (2001). Does Leadership Matter? CEO Leadership Attributes and Profitability under Conditions of Perceived Environmental Uncertainty, Academy of Management Journal, 44 (1), 134 - 143.

White, Darin W. (1998). The Impact of Environmental Uncertainty on Strategy Creation Style in a Franchise Channel Setting, Journal of Strategic Marketing, $6,273-304$.

A man's ideal, like his horizon, is constantly receeding from him as he advances towards it.

\section{- W.G.T. Shedol}


https://ir.iba.edu.pk/businessreview/vol5/iss2/4

DOI: https://doi.org/10.54784/1990-6587.1244

Business Review - Volume 5 Number 2

July - December 2010

Every one of us, unconsciously, works out a personal philosophy of life, by which we are guided, inspired, and corrected, as time goes on. It is this philosophy by which we measure out our days, and by which we advertise to all about us the man, or woman, that we are. . . . It takes but a brief time to scent the life philosophy of anyone. It is defined in the conversation, in the look of the eye, and in the general mien of the person. It has no hiding place. It's like the perfume of the flower ? unseen, but known almost instantly. It is the possession of the successful, and the happy. And it can be greatly embellished by the absorption of ideas and experiences of the useful of this earth.

- George Matthew Adams 